\title{
EXPERIENCE AND \\ TELEOLOGY IN ANCIENT HISTORIOGRAPHY
}

'Futures Past' from Herodotus to. Augustine

JONAS GRETHLEIN

Heidelbery University 


\section{CAMBRIDGE \\ UNIVERSITY PRESS}

University Printing House, Cambridge CB2 8Bs, United Kingdom

Published in the United States of Amcrica by Cambridge University Press, New York

Cambridge University Press is part of the University of Cambridge.

It furthers the University's mission by disseminating knowiedge in the pursuit of education, learning and research at the highest international levels of excellence.

$$
\text { www.cambridgc.org }
$$

Information on this titte: www.cambridge.org/978110704028

$$
\text { (c) Jonas Grethlein } 2013
$$

This publication is in copyright. Subject to statutory exception and to the provisions of relevant collective licensing agreements, no reproduction of any part may take place without the written permission of Cambridge University Press.

$$
\text { First published } 2013
$$

Printed in the Uniced Kingdom by TJ International Led. Padstow Cornwall A catalogue record for this publication is available from the British Library

$$
\text { Library of Congress Cataloguing in Publication data }
$$

$$
\text { Grethlein, Jonas, 1978- }
$$

Experience and teleology in ancient historiography : futures past from Herodotus to Augustine / Jonas Grethlein, Universitat Heidelberg. pages $\mathrm{cm}$

Includes bibliographical references and indexes.

$$
\text { ISBN 978-1-107-04028-r (hardback) }
$$

ı. History, Ancient - Historiography. 2. Rhetoric, Ancient -

Historiography. 3. History - Methodology. I. Title.

$$
\text { D56.G74 } 2013
$$

$$
930.072-\mathrm{dc2} 3 \quad 20 \mathrm{r} 300954 \mathrm{I}
$$

ISBN 978-I-IO7-04028-I. Hardback

Cambridge University Press has no responsibility for the persistence or accuracy of

URLs for external or third-party internet websites referred to in this publication,

and does not guarantee that any content on such websites is, or will remain,

accurate or appropriate.

Thr alle kennt die wilde Schwermut, die uns bei der Erinnerung an Zeiten des Glückes ergreift. Wie unwiderruflich sind sie doch dahin, und unbarmherziger sind wir von ihnen getrennt als durch alle Entfernungen.

Ernst Jünger, Auf den Marmorklippen 


\section{Contents}

Acknowledgments

page ix

Abbreviations

I Introduction: 'futures past' - historiography between experience and teleology

PART I. EXPERIENCE: MAKING THE PAST PRESENT

2 Thucydides, The History of the Peloponnesian War

3 Xenophon, Anabasis

4 Plutarch, Alexander

5 Tacitus, Annals

Summary of Part I

PART II. TELEOLOGY: THE POWER OF RETROSPECT

6 Herodotus, Histories

7 Polybius, Histories

8 Sallust, Bellum Catilinae

PART III. BEYOND EXPERIENCE AND TELEOLOGY

Io Epilogue: experience in modern historiography 


\section{Acknowledgments}

It is a pleasure to acknowledge the support of various kinds that I received while working on this book. Much of Experience and Teleology in Ancient Historiography was written in the East Coast idyll of Providence, Rhode Island where I spent the academic year 20IO/II as Gerda-Henkel fellow at Brown University. Many thanks to the Gerda-Henkel-Stiftung and Brown's Classics Department for an invaluable year of thinking, reading and writing! A research seminar at King's College, Cambridge, in February 20II allowed me to put three chapters to the test and provided much intellectual stimulation. I am most grateful to Robin Osborne for the invitation and splendid hospitality as well as to all participants for their probing questions. Further astute comments came from Chris Pelling and Kostas Vlassopoulos who responded to my paper at the Triennials 20II, also in Cambridge. I am fortunate to have in Bill Furley and Christopher Krebs two friends and learned philologists who read the entire manuscript with great care. I also benefitted from the expertise of Johanna Hanink, Bob Morstein-Marx and Kurt Raaflaub and their comments on individual chapters.

It would be impossible to name everyone from whom I have learnt in discussion and correspondence, but that does not prevent me from expressing my gratitude at least to Debby Boedeker, Angelos Chaniotis, Monika Fludernik, Renaud Gagné, Simon Goldhill, Christian Grethlein, Albert Henrichs, Marianne Hopman, Simon Hornblower, David Konstan, Ted Lendon, Elizabeth Meyer, Sara Monoson, Joe Pucci, Tim Rood, Michael Squire, Christian Tornau and Bob Wallace. I am also indebted to Sabine Hug, Benjamin Allgaier, Anne-Elisabeth Dönig, Helen Enders, Leonhard Graf von Klinckowstroem, Marie-Charlotte von Lehsten, Dominic Meckel and Steffen Schmieke for their assistance in formatting the manuscript. Helpful suggestions came from Michael Sharp and the two anonymous readers for the Press. I thank Martin Thacker for his thoughtful copyediting. The book is dedicated to Agnetha: can't take my eyes offyou. . . 
Parts of Sections I.III and Io.II draw on 'Experientiality and narrative reference. With thanks to Thucydides' History and Theory 49, 20I0: 315-35; Chapter 2 is a revised version of 'The presence of the past in Thucydides', in M. Tamiolaki and A. Tsakmakis, eds. Thucydides' Techniques. Between Historical Research and Literary Representation; Section 6.I expands on a section of 'How (not) to do history: Xerxes in Herodotus' Histories' AJPh 130, 2009: 195-2I8. I am grateful for permission to reuse these articles for this book. Part of the research leading to these results has received funding from the European Research Council under the European Union's Seventh Framework Programme (FP/2007-2013) / ERC Grant Agreement n. 31232I (AncNar).

My argument combines broad theoretical reflections on history and narrative with close readings of ancient texts. To make the argument accessible to readers with no Greek and Latin, I have added translations that, while forgoing elegance and sometimes even straining readability, attempt to convey the features crucial to my interpretation. I have consulted and used, with modifications, the following translations: Waterfield (1998) for Herodotus; Lattimore (1998) for Thucydides; Brownson (1998) [1922] for Xenophon; Paton (I922-7) for Polybius; Rolfe (I92I) for Sallust; Usher (1974-85) for Dionysius; Russell (200I) for Quintilian; Woodman (2004) for Tacitus; Babitt (1936) and Perrin (I9I4-26) for Plutarch; Cary (I9I4-27) for Dio; Sheed (20II) for Augustine. As to Greek names, I tend to adopt Latinized forms, except where familiarity dictates otherwise. The abbreviations of journals follow the Année Philologique, those of ancient authors the Oxford Classical Dictionary.

Blass-Thalheim

DK

FGrH

$I G$

Lex. Tac.

Peter

TLL

Usener-Radermacher

\section{Abbreviations}

F. Blass and T. Thalheim (eds.) (1914) Antiphontis Orationes et Fragmenta. Leipzig. H. Diels and W. Kranz (eds.) (r952) Die Fragmente der Vorsokratiker. 3 vols. (6th edn). Berlin.

F. Jacoby (ed.) (1923--) Die Fragmente der griechischen Historiker. Berlin. Inscriptiones Graecae (I873-) Berlin.

A. Gerber, A. Greef and C. John (eds.) (1877-1903) Lexicon Taciteum. 2 vols. Leipzig.

H. Peter (ed.) (1883) Historicorum Romanorum Fragmenta. Leipzig.

Thesaurus Linguae Latinae (1900-) Leipzig. H. Usener and L. Radermacher (eds.)

(I899-I929) Dionysii Halicarnasei Opuscula. 2 vols. Leipzig.

E.-M. Voigt (ed.) (1971) Sappho et Alcaeus. Fragmenta. Amsterdam. 
CHAPTER I

\section{Introduction}

\section{'Futures past' - bistoriography between experience} and teleology

\section{Experience and teleology}

The encounter of Croesus with Solon stands prominently at the beginning of Herodotus' Histories. Besides featuring a clash of worlds - Lydian king meets Greek sage - the episode helps to set the tone for the narrative, encapsulating Herodotus' take on history in nuce. Memorably, Solon hesitates to praise Croesus' version of bliss, pointing out that 'we must look to the conclusion of every matter, and see how it will end' ( $\sigma$ Ko $\pi \varepsilon \varepsilon$ iv

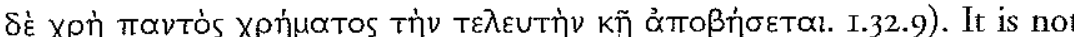
difficult to read this wisdom metaleptically as a reference to the Histories themselves: ${ }^{\mathrm{I}}$ a wealth of prolepses betrays Herodotus' interest in very recent and contemporary events, notably the intra-Hellenic conflicts in the second half of the fifth century, ${ }^{2}$ and yet his narrative ends with the year 479 BCE. A gap of two generations thus allows Herodotus to acquiesce to the maxim of the Histories' Solon and consider historical events from their end.

A very different view of how to narrate the past comes to the fore in an ancient comment on Herodotus' most prominent successor. In his treatise On the Glory of the Athenians, Plutarch turns to Thucydides to illustrate Simonides' dictum that poetry is a speaking painting (De glor. Ath. 347a):

Thucydides is always striving for this vividness in his writing, since it is his desire to make the reader a spectator, as it were, and to instil into readers the emotions of amazement and consternation felt by eyewitnesses.

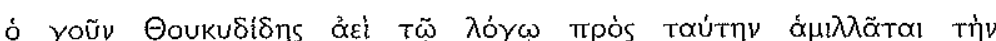

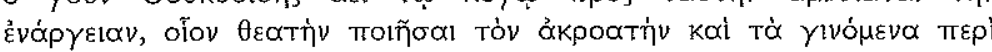

i See also Artabanus in 7.51.3; cf. Grethlein 2009b: 214

2 'This has been much commented on in scholarship, see, e.g., Fornara 197rb; Stadter 1992; Moles I996. 


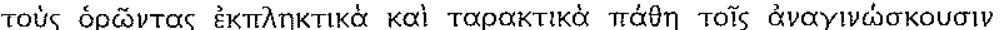

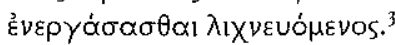

The visual quality of Thucydides' narrative lets the reader view the fighting at Pylos and the battle in the harbour of Syracuse as if they were just unfolding.

Solon's metaleptic comment on the Histories and Plutarch's reading of Thucydides describe two poles between which narratives of the past oscillate: teleology and experience. The historian can capitalize on the advantage of hindsight or try to render the past as it was experienced by the historical agents. It is the project of this book to explore this tension in ancient historical narrative. In this introductory chapter, I will chart its theoretical implications and thereby provide the framework for my readings as well as elucidating their relevance for the theory of history. After elaborating on teleology and experience in the remainder of this section, I will use Danto's concept of 'narrative sentences' as a stepping stone to conceptualize the tension between them that I label 'futures past' (II). I shall then turn to narrative and situate my approach in a current debate among theoreticians of history (III). In a final step, I will sum up the goals of Experience and Teleology in Ancient Historiography and give a synopsis of its argument (IV).

In the context of my argument, telos does not signify the historians' ulterior motives, e.g. to entertain or educate their readers, but the vantage point from which a course of events is told. Posteriority endows the historian with a superior stance the importance of which is nicely illustrated by an episode from Stendhal's La Chartreuse de Parme. The novel's hero, Fabrice del Dongo, desperately trying to join Napoleon's troops despite his young age and poor knowledge of French, witnesses the battle of Waterloo. Donned in the uniform of a French hussar, he wanders right onto the battlefield, joins the troops of Marshal Ney and is wounded in the leg. Although Fabrice is as present and as close as possible, the narrative focalized through his eyes tells us very little about the battle. This is not only due to Fabrice's imbecile character and his spatially limited vantage point, but also bespeaks the superiority which retrospect bestows on historians. Notably a couple of weeks later, after recovering from his injury, Fabrice tries to learn about the battle from journal articles and even wonders: 'What he had seen, was it a battle, and second, was this battle Waterloo?'4

${ }^{3}$ See also Plut. Nic. I.I; I.5. On Plutarch's manifold playful engagements with Thucydides, see Pelling I992.

4 Stendhal 2007: 87: 'Ce qu'il avait vu, était-ce une bataille, et en seconde lieu, cette bataille était-elle Waterloo?' On the discrepancy between the experience of a battle and later reports, see Tolstoy 2004
The temporal distance that at first sight appears as an impediment to the historians' work is, besides the access to multiple perspectives, one of their chief assets. Hindsight allows historians to evaluate events in the light of later events and make out links that are still invisible to the historical agents. The Austrian novelist von Doderer puts it beautifully in the words of the narrator of his Die Dämonen: 'Out of that past, what belongs together in truth (often without our knowing) gradually grows together; and related entities shake hands and bridge the gap of time even if they were widely separated from each other in life, in different years, at different places, without an accessible link between their environments.' ${ }^{\text {'5 }}$ Less poetic, but conveying more or less the same idea is a fragment from the second-century BCE annalist Fannius: 'When we have learned our lessons in life, then much that seems good at its time, turns out to be bad and many things are very different from what they seemed to be...' (cum in vita agenda didicimus, multa, quae inpraesentiarum bona videntur, post < mala $>$ inventa et multa amplius alius modi atque ante visa essent... fr. I Peter). It is crucial for historians to go beyond the perspective of their characters and view the past from the telos of events still anterior to them. ${ }^{6}$ Even David Carr, one of the most eloquent advocates of the role of experience in historiography, affirms this when he elaborates on the steps of historical reconstruction: in a first step, historians retrieve the events as experienced by the historical agents, they then compare the experiences of various characters and finally incorporate them in a new story from their own elevated point of view. ${ }^{7}$

At the same time, historians and philosophers have not tired of warning against the sway of teleology and have instead advanced a focus on the experiences of historical agents. To start with, two scholars who are not often mentioned in the same sentence may illustrate the reservations of historians against 'the enormous condescension of posteriority' $:^{8}$ in his diatribe against the 'whig interpretation of history', Herbert Butterfield attacks liberal historians who fail to do justice to the past by not seeing

in the second epilogue to War and Peace (1220-1); the battle narratives of this novel seem strongly influenced by Stendhal.

von Doderer 1956: I: 16: 'Aus jenem Vergangenem aber schwankt wie aus Nebeln zusammen, was aus Wahrheit zusammen gehört, wir wußten's oft kaum, aber jetzt reicht das verwandre Gebild dem verwandten die Hand und sie schlagen eine Brücke durch die Zeit, mögen sie auch sonst im Leben ganz weit auseinandergestanden haben, in verschiedenen Jahren, an verschiedenen Orten, zwischen denen eine recht eigentlich gangbare Verbindung der Umstände fehlt.' See also the impressive description of the view from the window that can be read as a metaphor for the historian's activity $(20-1)$.

${ }^{6}$ The advantage of hindsight is felt with particular force in the case of autobiography, cf. Freernan 1993: 108-9.

7 Carr 2006: 135. $\quad{ }^{2}$ Thompson 1966: 12. 
it in its own right, but 'produce a scheme of general history which is bound to converge beautifully upon the present'. With a very different political agenda in mind, E. P. Thompson, the doyen of British neoMarxist history, sets out to record the experiences of the English working class. $^{\text {Io }}$

From a more theoretical point of view, Raymond Aron had already observed in 1938: 'Retrospect creates an illusion of fatality which contradicts the contemporaneous impression of contingency.' analysis by historians should serve less to trace the great lines of history than to re-establish the uncertainty of the future for those who lived in the past. ${ }^{\mathrm{I2}}$ More than half a century later (and without taking note of Aron), M. A. Bernstein chooses a particularly sensitive subject for historical representation to challenge the tendency towards teleological constructions in historiography and objects that the Shoah is envisaged as unimaginable and inevitable at the same time. ${ }^{13}$ This perspective fails in particular to do justice to the experiences of the Jewish population before the Nazis' destructive machinery started up. From yet another angle, Lucian Hölscher notes that historical reconstructions neglect past views of the future and suggests an 'archaeology' which moves through the layers of earlier historical reconstructions to the events themselves and envisages them in the horizon of their own time. ${ }^{\mathrm{I}}{ }^{4}$

Teleology and experience are obviously at loggerheads: the more historians cash in on hindsight, the further they move away from the perspective of the historical agents. Trying to write history as it was experienced, on the other hand, requires renouncing the superior stance of retrospect. That said, teleology and experience are not without links. As emphasized by Heidegger in Sein und Zeit, human life is directed towards the future. We anticipate the future with a wide variety of feelings ranging from fear to hope. This variety notwithstanding, the anticipation of the future by historical agents prefigures the teleologies of historians. Needless to say, the goals pursued by humans are not necessarily identical with the tele from which their lives are later told, but nonetheless embed in the world of experience a structure that is homologous to the teleologies of historical narratives. ${ }^{15}$

9 Butterfield x93r: 12. 10 Thompson 1966

"I Aron 1938: 18: 'La retrospection crée une illusion de fatalité qui contredit l'impression contemporaine de contingence.

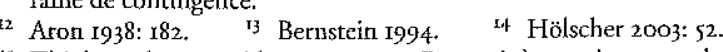

15 This homology provides an answer to Bernstein's question as to why to privilege the end of something (1994: 29). This is not an arbitrary imposition by historians as he insinuates, but corresponds to the structure of human action itself.
It seems that the experiential quality of historical narrative is deeply rooted in our interest in the past. Some branches of current historiography may revel in numbers, statistics and maps, but, together with the work of many professional historians, the flourishing industry of the historical novel bespeaks a desire to know what it felt like to lie face to face with Cleopatra, to join a crusade or to be on board the Mayfower. Gumbrecht takes this aspect further when he argues that our interest in the past originates in the desire to transgress the limits of our Lebenswelt. Applied to time, this means: 'We want to know the worlds that existed before we were born, and experience them directly. ${ }^{36}$ Linked to the wish to feel with past generations is the urge to experience them oneself in some way. Another aspect of experiential historiography is that it lends itself to recovering the possibility of agency in the flow of history. While teleology often tends to trace lines beyond the grasp of historical protagonists, the focus on experiences suits well a view of history as the product of individual agency. ${ }^{17}$

Besides being fostered by the retrospect with which we view the past, teleology appears to answer another deep-seated desire. While we are exposed to the vagaries of the future in our lives, the past offers a closed realm. Hermeneutics reminds us that there is no definitive narrative of the past, that different angles are possible and that the further processing of time will continue to open new ones, ${ }^{18}$ but, within the retrospect of a single narrative, all the openness and insecurity that make life just as troublesome as exciting can be banned. The look back permits us to master the contingencies to which we are subject in life, to replace vulnerability with sovereignty. Teleology can thus serve as a means of coping with temporality.

Following the pull to be in touch with the past as well as the desire to overcome the vagaries of time, experience and teleology arguably constitute the core of our interest in the past. Beginning with Herodotus, historians have of course prided themselves on their accuracy and methodological rigour,

I6 Gumbrecht 1997: 419.

17. It ought to be emphasized that these are only tendencies: If the telos is identical with an agent's goal,

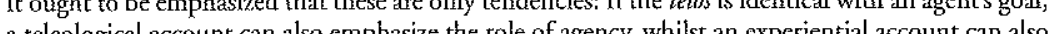
a teleological account can also emphail
highlight failures of historical agents.

I8 In the words of a character of Die Dämonen, the historian Neuberg (Iog): 'Jedesmal aber muß die In the words of a character of Die Dämonen, the historian Neuberg (I09): Jedesmal aber muß die ganze Vergangenheit neu geordnet und gesichtet werden, da ja jedesmal ihr Schwerpunkst, nach welchem sich alles richten muß, anderswohin verschoben ist: nammich in eine andere Gegenwart und das heilst aber zugleich auch in einen anderen jezz tefinnerlich verwandten und höchst gegenwärtigen Teil der Vergangenheit.' ('Yet, every time the entire past has to be ordered and envisioned anew, because every time its centre of gravity, to which all things tend, shifts to another place, namely to another present and that means simultaneously to another point in the past that is deeply related and truly present.') 
thereby setting their reconstructions apart from non-scholarly views. ${ }^{19}$ And yet, historiography is rooted in our everyday interest in the past. ${ }^{20}$ While the political aspects of ancient historiography have received much attention, an exploration of the tension between experience and teleology lets us elucidate a more existential aspect and view historiography as a means of coming to grips with temporality.

\section{From 'narrative sentences' to 'futures past'}

Arthur Danto's idea of 'narrative sentences' can help us conceptualize the tension between teleology and experience that underlies historiography. In his analytical philosophy of history, Danto observes that historians are fond of a particular type of sentence: 'Narrative sentences refer to at least two time-separated events, and describe the earlier event. ${ }^{\text {'2 }}$ The statement 'The Thirty Years' War began in $1618^{\prime}, 22$ for example, is about an event in 1618 that is seen against the horizon of a later event, the year 1648 . Danto limits his analysis to single sentences, but I contend that the structure of 'narrative sentences' also defines narratives of the past as a whole: the retrospect makes historians view the past in the light of subsequent events. The vantage point historians choose influences the selection of the material as well as its arrangement and thereby gives historical narratives their character. The later event against which the earlier event is described in Danto's narrative sentences recurs mutatis mutandis as the telos in a historiographic work.

This telos is distinct from, albeit dependent on, the horizon of the historians' present; the historians' reconstruction ought therefore not to be mixed up with Gadamer's notion of 'Horizontverschmelzung'. ${ }^{23}$ The fusion of our horizon with the horizon of our object that is part of any act of understanding also applies to historians and explains why every age has to narrate the past anew. It is not necessary that the present of the historians forms the telos of the events they narrate. While the historians' understanding of their subjects is influenced by the horizon of their present, the telos of their narratives can also be in the past, ${ }^{24}$ often the endpoint or

r9 Cf. Grethlein zoroa and 2orrb for a new assessment of the rise of Greek historiography in the tension between innovation and continuity with other genres.

2o For this take on history which is indebted to the phenomenological tradition, see the introductions For this take on history which is incterin 2006a and 2oloa.

${ }^{21}$ Danto 1985: 159. ${ }^{22}$ CE. Danto 1985: 152

${ }^{23}$ See especially Gadamer 1986: 275-83. Habermas blurs the discinction when he embeds a discussion of Danto's 'narrative sentence' in his review of Wahrbeit und Methode (1977: 342-SI).

${ }^{24}$ To be precise, the telos necessarily belongs to the past as the act of retrospective writing is always posterior to the events covered. climax of their narratives, for example the final victory in a war monograph or the death of the hero in a biography. While belonging to the general hermeneutics of understanding, the temporal poetics of historical writing are not identical with them.

Certain events such as military victory and death suggest themselves as telos, but the vantage point from which specific historic events are told is as undetermined as it is crucial for their understanding: a history of Germany in the 1920s, for instance, can be told from the vantage point of the economic crisis casting its shadow in 1929 or from the vantage point of the Shoah, to mention just two possibilities. While in the first case Adolf Hitler and his political agitation would barely be mentioned, the Beer Hall Putsch and Mein Kampf would figure prominently in the second.

The Peloponnesian War furnishes an ancient example of the possibility of various tele and their impact on how we understand the past: Thucydides' narrative, as we have it, breaks off in mid-sentence, but passages such as the evaluation of Pericles in 2.65 and the second proem in 5.26 make it clear that the defeat of Athens in $404 \mathrm{BCE}$ is the telos of The History of the Peloponnesian War. Thucydides' picture of the Peloponnesian War is so powerful that we have come to take it for granted, but other endpoints, conditioning rather different storylines, are thinkable, too. Dionysius, for example, takes issue, among other aspects, with the ending of Thucydides' account. While he levels his critique at the point where The History of the Peloponnesian War breaks off, obviously assuming that it is the intended endpoint, his suggestion of an alternative telos nonetheless illustrates an interpretation of the Peloponnesian War that is at odds with the one that we glean from the fragment of The History of the Peloponnesian War (Pomp. 3.IO, 77 Usener-Radermacher):

It would have been better, after going through all the events, to end his history with a climax, and one that was most remarkable and especially gratifying to his audience, the return of the exiles from Phyle, which marked the beginning of the city's recovery of freedom.

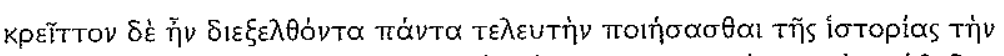

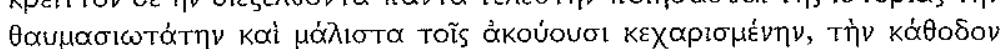

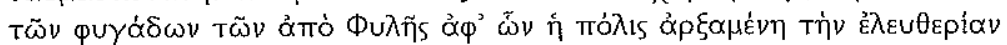
ờ

Whereas the telos of 'Thucydides' account creates a sombre picture of Athenian history, the vantage point favoured by Dionysius would have it 
end on an up-beat note. ${ }^{25}$ Instead of being the story of a mighty polis brought down by a corrupt political system, the Peloponnesian War would appear as the pertinacity of the Athenian democracy through a host of hardships and trials.

The very notion of a single Peloponnesian War lasting from $43 \mathrm{I}-404 \mathrm{BCE}$ is far from being the only way of viewing the history of this time, as several texts from the fourth century reveal: Andocides and Aeschines consider the hostilities in $43 \mathrm{I}-42 \mathrm{I}, 4 \mathrm{I} 9 / 4 \mathrm{I} 8$ and $4 \mathrm{I} 5-404 \mathrm{BCE}$ as distinct wars just as Socrates in Plato's Menexenus distinguishes between the battles of Tanagra and Oenophyta, the Ten Years' War and a 'third war', arguably covering $4 \mathrm{I} 5-404 \mathrm{BCE} .{ }^{26}$ Needless to say, envisaged against the background of the Nicias Peace, the first years of the Peloponnesian War read very differently from Thucydides who takes the break-down of Athens in 404 BCE as his vantage point.

The choice of a vantage point is the fulcrum on which historians balance experience against teleology in their narratives. Those who downplay hindsight and align their perspectives with the historical agents will foreground contemporary experience. Capitalizing on retrospect, on the other hand, and choosing vantage points remote from the agents leads to strong teleologies. I suggest calling the underlying temporal dynamics 'futures past'. ${ }^{27}$ Besides entwining retrospect with prospect, the term captures the asymmetry between characters and historians - what is still future for the former, is already past for the latter - and signifies the point that regulates the balance between experience and teleology: the stronger the future in a given narrative's 'futures past', the stronger its focus on experience; the more the 'futures past' is treated as past, on the other hand, the more prominent becomes its teleology.

Most historiographic works feature elements of both experience and teleology. Accounts that fully ignore the perspective of the agents tend to be unsatisfying, as shown in Quintilian's comparison of a lapidary statement that a city was conquered, with a colourful account including the feelings of the conquered: '... to state the whole is less than to state all the parts'. (. . . minus est tamen totum dicere quam omnia. Inst. 8.3.69.) On the other hand, it is hard, if not impossible, to escape hindsight entirely given that

25 CF. Marincola 2005: 305; Fromentin 2008: 61.

${ }_{26}$ Andoc. 3.3-9; 29-31; Aeschin. 2.173-6; Pl. Menex. 242e-3b. Cf. de Ste. Croix 1972: 294-5.

${ }_{27} \mathrm{My}$ use of 'futures past' is distinct from Koselleck's. His 1979 book bears the main tidle Vergangene Zukunft that is rendered as Futures Past in the title and as 'former future(s)' in the text of the English translation (cf. the translator's note in Koselleck I985: $\mathrm{xi}_{\mathrm{n}}^{\mathrm{n}} \mathrm{n}$. I3). While Koselleck is interested in the translation (cf. the translator's note in Koselleck 1985 : $x i$ n. . 33 ). While Koselleck is interested in the temporal asymmetry of agents and historians in the sense outlined above. our view of the past is retrospective. It seems that the combination of both is crucial to our engagement with the past. ${ }^{28}$ The blessing of hindsight is felt only against the background of the agents' experience which in turn demands retrospect to be understood. Historical explanation requires both: in order to explain a course of events we need to know both where they are headed and how this end was reached. ${ }^{29}$ While most historical narratives thus contain both experience and teleology, they weight and express them differently, as my readings of various ancient works will illustrate.

\section{Narrative and experience}

After elaborating on the concept of 'futures past' as defining the asymmetry between agents and historians, it is time to turn to narrative and consider its capacity to express teleology and experience. The power to express hindsight in narrative needs no further argumentation, as its teleological leanings are well known. The posteriority of the act of narrating comes to the fore in the privileging of the past tense in narrative. ${ }^{30}$ Thomas Mann's narrator in Joseph und seine Brüder can therefore ask in his Höllenfahrt that explores the depth of the fountain of history: 'Is not the past the element of the narrator and his life-breath, familiar to him as temporal mode and appropriate as water is to fish?'?

The case for narrative and experience has been made by Monika Fludernik, who in Natural Narratology sets out to define 'narrativity' as mediated 'experientiality', that is 'the quasi-mimetic evocation of real-life experience' ${ }^{32}$ Introspection is the most obvious means of expressing the experiences of characters in narrative; accordingly the modernist novel

${ }^{28} \mathrm{I}$ am therefore hesitant to follow Strasburger in his polarization triggered by a reflection on Polybius' critique of Phylarchus (1966: 83): 'Wird der Mensch ïber Gang und Wesen der Geschichte sachgerechter belehrt durch den Verstand oder das Gefühl, durch das Sich-Erheben zu nüchterner Betrachtung der pragmatischen Zusammenhänge von hoher Warte aus oder durch den Versuch, Betrachtung der pragmatischen Zusammenhange von hoher Warte aus oder durch den Versuch, die Realität, welche Geschichte für die von ihr handelnd and leidend Betroffenen hatte, in voller Instensität nachzuerleben??' ('Does one learn more about the course and essence of history from intellect or feeling, from rising to sober consideration of pragmatic links from high abovc, or from the attempt to re-experience with full intensity the reality that history had for those who were affected by it in acting and suffering?') With admirable lucidity, Strasburger identifies here the tension between experience and telenlogy as a central question, but he does not recognize their intricate interaction.

29. I owe this important point to Chris Pelling.

On the importance of retrospect for narrative, see, e.g., Abbott 20o5; on the past tense as expressing 'Sinnabgeschlossenheit', see Wolf 2002: 49. On teleology in narrative, see also Ajouri 2009.

31 Mann 1960: I: 53: 'Ist nicht das Vergangene Element und Lebenslutt des Erzählers, ihm als Zeitfall vertraut und gemäß wie dem Fisch das Wasser?'

${ }_{32}$ Fludernik 1996: 12. However, Fludernik denies the presence of experientiality in historiography, a position that I will challenge in the Epilogue. 
with its focus on processes of consciousness is a prime example of Fludernik's definition of 'narrativity'. In this section, I would like to go beyond Fludernik's analysis and demonstrate why narrative lends itself to the representation of experience. Narrative, I hope to show, permits us not only to learn about past experiences, but also, within certain boundaries, to re-experience them. My argument takes up the recent interest of theoreticians in the experience of the past while challenging their tendency to pit it against narrative. Let me first discuss two examples of this trend in more detail to chart the contribution that the angle of 'futures past' can make to the current debate. ${ }^{33}$ I will then elaborate on narrative re-experience, briefly touch upon the special case of historiography and finally throw my approach into relief through a comparison with the ancient concept of enargeia.

\section{'The New Romanticists'}

The recent turn from narrative to experience in the theory of history is nicely illustrated by the works of Frank Ankersmit. After following Hayden White's lead and elaborating on a rhetorical theory of history, ${ }^{34}$ Ankersmit grew more and more interested in how we experience the past. In Sublime Historical Experience (2005), Ankersmit challenges the linguistic transcendentalism that he finds not only in tropology, but also in hermeneutics, semiotics, and deconstruction. Experience, Ankersmit argues, precedes language and is incommensurate with narrative. ${ }^{35}$ Historians, too, experience the past before they represent it. The experience of the past takes place in the tension between 'discovery' and 'recovery'. The 'loss' of the past is countered by 'love', the desire for it: 'The sublimity of historical experience originates from the paradoxical union of the feelings of loss and love, that is, of the combination of pain and pleasure in how we relate to the past. ${ }^{36}$ Ankersmit stresses that his new approach is not meant to recant his earlier works, but sheds light on how historians access the past before they set out to represent it. Nonetheless, the conceptualization of historical experience necessitates a turn from postmodern theory with its focus on linguistic representation to a 'New Romanticism' of experience, especially feeling.

A good deal of Romanticism has also been discerned in Gumbrecht's reflections on history. ${ }^{37}$ I have already referred to his observation that the desire to transgress the limits of our everyday world brings with it a

33 For a lengthier version of the following argument, see Grethlein zorob.

34 Ankersmit 1994: 200I. ${ }_{35}$ Cf. Ankersmit 2005: 172-3. ${ }_{36}$ Cf. Ankersmit 2005: 9

37 Cf. Kramer 2009: 85-97. yearning to experience the past. According to Gumbrecht, the sensual aspect of this yearning has long been marginalized, but has come to the fore more recently in the enthusiasm for archives, the attention to historical detail in movies, and the popularity of museums. Like Ankersmit's, Gumbrecht's interest in experience goes hand in hand with a rejection of narrative, albeit for different reasons. Narrative, Gumbrecht argues, has been closely linked to the didactic claims of history and has lost its plausibility with the discrediting of the topos historia magistra vitae. In his book 1926 , Gumbrecht thus puts forward an experiment in non-narrative historiography. He represents this year 'at the edge of time' on three synchronic levels. Under the heading of 'arrays', topics such as 'Americans in Paris', 'boxing', and 'League of Nations' are described. The 'codes' include 'authenticity versus artificiality', while the third part is devoted to 'codes collapsed', for example 'authenticity = artificiality (life)'. In this way Gumbrecht tries 'to conjure some of the worlds of 1926 , to "re-present" them, in the sense of making them present again. To do this with the greatest possible immediacy achievable through a historiographic text (as opposed to, say, photographs, sound-documents, or material objects). ${ }^{38}$

1926 is brilliantly written and full of fascinating observations, and Gumbrecht's 'presentism' has struck a chord with many theoreticians. ${ }^{39}$ Eelco Runia, for example, has made a case for a turn from 'representationalism' to 'presentism'. Besides or even before the meaning of history, there is 'the unrepresented way the past is present in the present'. While the meaning of history is constructed in metaphors, it is the figure of metonymy that grasps the past's presence. ${ }^{40}$ Nonetheless, despite the timeliness of Gumbrecht's approach, its case against narrative is open to challenges. Didactic history may have depended on narrative, but it does not follow that once didactic history has lost its plausibility, narrative is thereby discredited. 1926 itself belies the programmatic reflections of its author, for much of its brilliance is owed to the splendid narratives embedded in the descriptions. The appeal and dilemma of 1926 rests on an awkward combination of historiographical goal and medium. Thanks to its sequentiality, the medium of language is well suited to represent developments, whereas material relics are traces in which the past can be grasped metonymically. ${ }^{4 \mathrm{~T}}$ Gumbrecht, however,

${ }^{38}$ Gumbrecht 1997: x.

39 Part of Gumbrechr's appeal is the easy accessibility of his argument. Mersch 2002 presents a philosophically more profound case for presence that precedes, or is at least parallel to, meaning.
40 Runia 2006: $\mathrm{I}-29$. See also the 'Forum on Presence' in History and Theory 45, no. 3 (2006) and Froeyman 2012.

${ }^{4}$ It is therefore not surprising that scholars such as Eva Domanska combine their presentist approaches with a focus on materiality (2006). 
uses language to make the past tangible, and in the process reveals not so much that experience can replace narrative, but rather that a tension exists between the two.

Ankersmit's and Gumbrecht's interest in experience is to be welcomed as it highlights aspects that have long been neglected in history. ${ }^{42}$ At the same time, their reflections do not do justice to narrative. Polemics against narrative can be understood as part of the reaction against the linguistic turn, but, I think, seriously understate the capacity of narrative and thereby also impair our understanding of experience and history. A fresh look at experience and narrative will reveal the potential of the latter to express the former.

\section{Narrative re-experience}

The relationship between experience and narrative is manifold. In a long tradition reaching from Aristotle to Auerbach, scholars have viewed narrative as a form of mimesis, often of experience. At the same time, experience seems to depend on narrative. Drawing on Merleau-Ponty's 'paradox of expression', ${ }^{43}$ Bernhard Waldenfels considers the 'paradox of narrative' and states: 'Narrative refers to an experience which gains shape only in the process of narrating and re-narrating.' 44 David Carr even argues that experiences themselves have narrative structures. ${ }^{45}$ Of course, experience and narrative are not identical; rather, they are mutually dependent on each other. On the one hand, narratives refer to experiences, while on the other, experiences are fixed in the form of narratives.

The point that is crucial to my argument focuses in on a different aspect, namely that narratives lead to experiences. Whoever reads or listens to a narrative has a reception experience. Reflection on the nature of this experience triggered by narratives in general will help us reconsider the value of narrative to express past experiences. The character of aesthetic experiences has been elucidated by Hans-Robert Jauß, who compares the 'aesthetic attitude' with role-playing in the everyday world as analysed by Helmut Plessner and writes: 'Both modes of experience require that human beings double themselves in adopting a given role.' There is, however, also

42 Although the idea of experience has not fared well under the auspices of the linguistic turn, it has been used by theoreticians and historians, e.g., Thompson 1966; for a survey, see Jay 2005

43 Merleat-Ponty 1945: 442-7.

44 Waldenfels 2004: 50: 'Die Erzählung bezieht sich auf eine Erfahrung, die erst im Erzählen und Wiedererzählen Gestalt pewinnt.'

4 Cf. Carr 1986. a difference: aesthetic role-playing 'creates awareness of the doubling which is implied in all role-playing and allows enjoying oneself in the experience of the role'. ${ }^{6}$ 'The aesthetic distance, the 'as-if of fiction, is fundamental: 'Aesthetic pleasure, which takes place in the balance between disinterested contemplation and experiential participation, is a way of experiencing oneself in the experience of the other.' 47

The experience of oneself in the experience of another is an important aspect, but a point to which Jauß does not really pay attention seems to me even more important: the temporal structure that aligns reception experiences with experiences in the Lebenswelt. ${ }^{4}{ }^{8}$ Hans-Georg Gadamer's reflections on experience in Wabrheit und Methode provide us with a good starting point for charting the temporality of reception experiences. ${ }^{49}$ Gadamer rejects tendencies to deprive experience of its historical dimensions and thereby to make it objective; instead, he harks back to Hegel. Unlike Hegel, Gadamer does not view self-knowledge as the telos of experience, but he adopts the earlier philosopher's assumption that experiences disappoint expectations: 'Any experience worthy of this name thwarts an expectation. The historical being of man thus implies, as a trait of its nature, a fundamental negation that comes to the fore in the intrinsic relation between experience and insight. ${ }^{\prime 0}$ This is particularly evident in painful experiences, but it is also the case in pleasurable ones where what makes an experience an experience is the structure of experience itself, namely, that it interrupts the normal flow of what is usual. Experiences are disruptive by structure rather than by content. ${ }^{\text {sI }}$

We can thus say that experiences always involve our expectations, an observation on which Koselleck has capitalized in his 'semantics of historical time. ${ }^{52}$ The temporal structure of our consciousness, with its chain of reand protentions, leads us to direct expectations of the future, expectations that are either confirmed or disappointed by experiences. ${ }^{53}$ Even what is

$4^{6}$ Jauß I982: 226-7: 'Für beide Erfahrungsweisen wird vom Menschen erfordert, sich mit der Aufnahme einer vorgegebenen Rolle zu verdoppeln... [Das ästhetische Rollenverhältnis...] macht nurmehr die Verdoppelung, die allem Rollenverhalten inhärent ist, kontrastiv bewußt und ermöglicht es, sich selbst in der Erfahrung der Rolle zu genießen.'

47 Jauß 1982: 85: "Ästhetischer Genuß, der sich derart in der Schwebe zwischen uninteressierter Kontemplation und erprobender Teilhabe vollzieht, ist eine Weise der Erfahrung seiner selbst in der Erfahrung des anderen.

$4^{8}$ The reflections of Jauß 1982: 39-40 are vague. 49 Gadamer 1986: 352-68.

50 Gadamer 1986: 362: 'Jede Erfahrung, die diesen Namen verdient, durchkreuzt eine Erwartung. So enthält das geschichtliche Sein des Menschen als ein Wesensmoment eine grundsäzzliche Negacion, die in dem wesenhaften Bezug von Erfahrung und Einsicht zutage tritt'

sisee, for example, Waldenfels 2004: 55, and, from a Husserlian perspective, Tengelyi 2007: 19.

\$2 Koselleck 1979: 349-75.

53 Cf. Tengelyi 2007: 9 . 
absolutely unexpected, something that has not even been deemed unlikely, upsets a prior expectation or, to be more exact, the horizon of expectations.

Narratives generate the tension between expectations and experiences at two levels. First, the plot features experiences as the characters have expectations that are realized or not by the action. Second, the recipients of the narrative harbour expectations concerning the plot and on this basis have reception experiences. The relation between the experiences of characters and readers is, I would argue, crucial to the dynamics of narrative. It can be shaped in various ways: in the Homeric epics and Greek tragedy, for example, the narrator provides his narratees with prolepses and thereby privileges them over the characters who have no insight into the future. Many detective novels, on the other hand, are effective in withholding information from readers and thereby raising suspense. Yet other stories, notably by modernist authors, strongly focalize the action through characters and thereby align readers with them.

The doubling of experience is, I believe, a major reason for the ubiquity of narrative in the most diverse cultures and periods of history. In another paper, I argue that narrative allows us to experience, without the constraints of the everyday world, the tension between expectation and experience that underlies our lives. ${ }^{54}$ For my argument here, the way of orchestrating narrative mentioned last is of particular interest, as it makes the experience of the reader follow the experience of the characters. This, however, goes against the teleological drive that inheres in narrative through the retrospective stance of the narrator. Even if the narrator does not explicitly reveal his superior knowledge, teleology is deeply inscribed in the construction of many narratives. 59 As Chekhov notes: 'If in the first chapter you say that a gun hung on the wall, in the second or in the third chapter it must without fail be discharged. ${ }^{56}$ Narrative economy, here the readers' knowledge that details tend to be relevant for the plot, privileges readers over characters. That being said, the teleological drive of narrative can be minimized through what Morson calls 'sideshadowing': 'By focussing on the middle realm of possibilities, by exploring its relation to actual events, and by attending to the fact that things could have been different, 'sideshadowing' deepens our sense of the openness of time.' 57 In the works of Dostoevsky and Tolstoy Morson finds instances of this attempt to avoid the impression of inevitability fostered by the retrospective vantage point. 'Sideshadowing' devices recreate the situation in which the characters find themselves.

54 Grethlein 2orod. Bubner 9989 harks back to Kant's third Kritik to emphasize the significance of the 'as-if' for aesthetic experience in general.

s5 See, e.g., Brooks r984. 56 Chekhov r974: 23. 57 Morson 1994: 6.

\section{Re-experience in historiographic narrative}

Morson identifies 'sideshadowing' in fictional narrative, but it is not limited to fiction and is also possible in historical narrative. There it is admittedly more difficult to achieve as historians narrate the past which, unlike the content of novels, is known. However, readers may be familiar only with the major developments, and many details and entire storylines will be new to them. Cognitive research has also shown that there can be suspense in the process of rereading..$^{8}$ 'Tricky as it is in historical narrative, 'sideshadowing' is highly significant for the question of how to get in touch with the past. Strategies of 'sideshadowing' let the readers not only learn about the experience of historical agents, but re-experience it. Readers face the same openness of the action as the characters, and like them are forced to conjecture about its further development and then find their expectations confirmed or disappointed by its outcomes. Used in historical narrative, 'sideshadowing' makes the past present again.

This 're-presentation' of the past can take on very different forms: just as reality is perceived differently, the re-experience triggered by historiography can follow various perspectives. The action narrated can be seen through the eyes of a detached observer or an agent, of a victim or a perpetrator, of a marginal or a powerful instance. While these perspectives will yield very different, even contradictory accounts, they all converge in considering history not as a given past, but as a present.

The significance of 'sideshadowing' for historiography can be seen in the light of the problems it raises. As subsequent chapters will amply illustrate, some of the most powerful devices of 'sideshadowing' draw on fictional elements. In Thucydides, for example, speeches and introspection are crucial to restoring presentness to the past, though in most cases they are arguably fictional. .9 Yet even in these cases, 'sideshadowing' contributes something to the representation of the past. The concept of a 'narrative reference' helps us assess the costs and benefits of this technique. I employ the term 'narrative reference' by analogy with Paul Ricoeur's notion of 'metaphorical reference'. In his seventh study on metaphor, Ricoeur demonstrates that metaphors derive their metaphorical meaning from the failure of literal meaning and, parallel to this, gain a second-order reference from the suspension of reference. ${ }^{60}$ In the same vein, I would argue, the speeches in

${ }^{88}$ See Gerrig x989a: 277-80; 1989b: 633-48; Brewer 1996 .

59 As the cases discussed in the Epilogue illustrate, even some modern historians are willing to experiment with fictional devices in order to restore presentness to the past.

60 Ricoeur 1975: 273-321. 
Thucydides have the function of a second-order reference. Although the speeches he recounts are not the words that were actually uttered, such that these speeches referentially fail as reports of what in fact was said, they do recreate the presentness of the past and thereby take on a referential function at a secondary level. The sacrifice of literal truth in a positive sense permits a reference to and 're-presentation' of the openness of the past.

The notion of a 'narrative reference' mediates between the claims of the linguistic turn and the 'New Romanticism'. It takes up the new interest in experience, but elaborates on narrative's capacity to convey it. The reexperiencing of the past through narrative for which I argue needs to be qualified though. I have already touched upon a fundamental difference between readers and characters which bears drawing out more fully: while the characters have real experiences, the experiences of the recipients take place in the mode of 'as-if'. Only the senses of sight and hearing, but not the other senses including the most 'pathic' sense of touch, are involved. More important, readers are not directly affected by what they read. Their experience is vicarious as it is directed towards the experiences had by others. Nonetheless, experiences in the mode of 'as-if' have the same temporal structure as real experiences. They unfold the same chain of pro- and retentions in the consciousness of readers, and are therefore legitimately considered experiences by Husserl. '61 'Narrative re-experience' can therefore be defined as the experience of the same temporal openness concerning the plot that the characters are subject to with regard to their future, and accordingly the experience of the same emotions but in an 'as-if' mode.

To sum up, due to its reconfiguration of human time, narrative proves a particularly apt medium for the representation of experience. There is a tension between narrative and experience, but far from only opposing experience, narrative can express past experiences and even let its readers reexperience them in the present. While being a medium of representation, narrative has the capacity to put us in touch with the past. In restoring its temporal horizon, it makes us suspend hindsight and envisage its future not as the past that it has already become for us, but as the future that it still was for the historical agents.

\section{Narrative re-experience and enargeia}

A focus on the experiential quality of narrative seems particularly appropriate for a culture such as classical Antiquity which emphasizes the spell

6r On the temporal structure of consciousness, see Husserl 1928. On the expcriential character of fictional acts, see Husserl I950: III: 78; $2006: 168$. words cast over their recipients. Gorgias, for example, calls the logos a

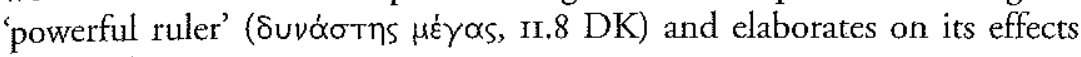
(II.9 DK):

Into those who hear it comes fearful fright and tearful pity and mournful longing, and at the successes and failures of others' affairs and bodies the mind suffers, through the words, a suffering of its own.

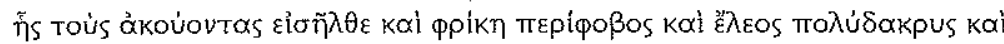

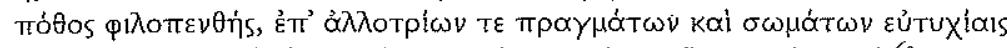

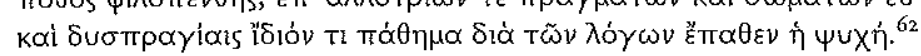

Gorgias rates poetry's grip on listeners so highly that he equates it with real life experiences without qualifications. This emphasis on the 'pathic' dimension of reception corresponds with the violence attributed in (Pseudo-)Longinus Subl. I5.9 to the rhetoric phantasia that 'not only

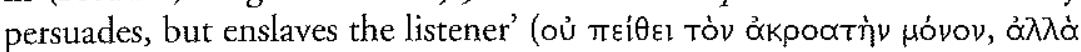

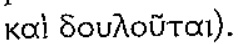

The term of phantasia is closely linked to the concept of enargeia that figures prominently in ancient treatises on literature and rhetoric. ${ }^{63}$ An exemplary definition can be found in the Lysias of Dionysius Halicarnassus (7):

This consists in a certain power he has of conveying the things he is describing to the senses of his audience, and it arises out of his grasp of circumstantial detail. Nobody who applies his mind to the speeches of Lysias will be so obtuse, insensitive or slow-witted that he will not feel that he can see the actions which are being described going on and that he is meeting face to face the characters whom the orator introduces.

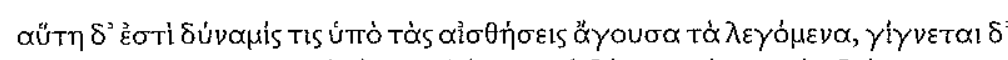

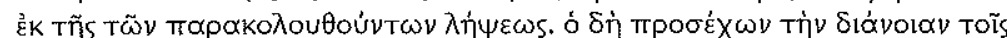

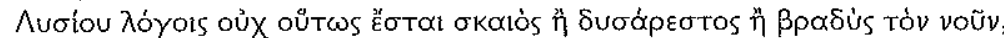

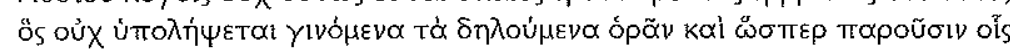

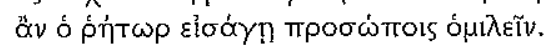

Enargeia features in discussions not only of oratory, but also of historiography. ${ }^{64}$ I have already quoted Plutarch's praise for the graphic qualities of

62 Cf. Segal 1962: 120-7.

${ }_{63}$ See Zanker 1981; Manieri 1998; Otto 2009: 67-134. On enargeia and phantasia in the progymnasmate of the Imperial age, see Webb 2009: 87-130.

${ }_{4}$ Cf. Manieri 1998: I55-64. See also Scheller rgrr: 57-6I; 65-7I; Strasburger 1966: 78-86; Walker 1993. [Dion], On mistakes in delamation, 27 even rants apinst the use of ekphrasis, com1993. [Dion.], On mistakes in declamation, 27 even rants against the use of ekphrasis, comagainst taking this as evidence for a non-rhetorical origin of ekphrasis in historiography or poetry. 
Thucydides' writing. Lucian, to give another example, reflects on enargeia in historiography in general (Quomodo historia conscribenda sit $5 \mathrm{I}$ ):

The task of the historian is similar: to give a fine arrangement to events and illuminate them as vividly as possible. And when a man who hears him thinks thereafter that he is actually seeing what is being described and then praises him - then it is that the work is perfect and has brought our Phidias of history its proper praise,

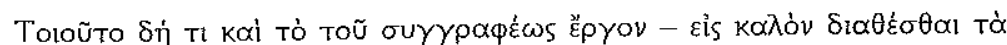

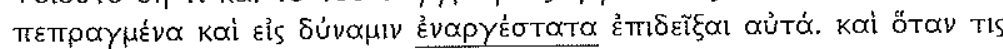

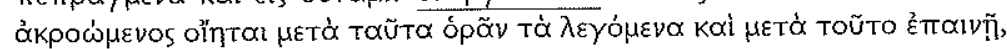

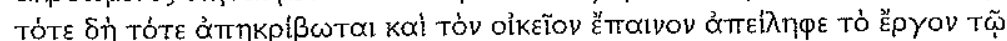

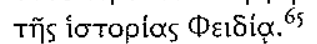

The ancient concept of enargeia prefigures in some respects my focus on the experiential aspect of narrative, but is not identical with it. While the idea of the recipient 'meeting face to face the characters' (троo $\omega$ trots $\delta \mu \imath \lambda \varepsilon \tilde{v} v$, Dion. Hal. Lys. 7) is close to my notion of restoring presence to the past, it is accentuated differently. The most salient aspect of enargeia, rooted in the word's etymology, is visual appeal. ${ }^{66}$ The Anonymus Seguerianus, for instance, defines enargeia as 'speech bringing what is being explained

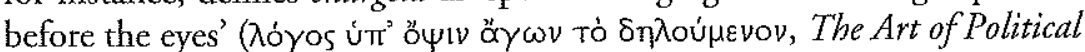
Speech 96). Time and again in the course of this study, we will encounter graphic scenes that enhance the mimetic appeal of an account, but visual quality is not the core element of experiential narratives. As defined in this section, the experience triggered by narrative hinges on its temporal sequence which can be made to mimic the sequence of past events. Most detailed descriptions, on the other hand, bring narrated time to a pause; they may help the reader to visualize the settings of the action, but also interrupt the mimesis of its sequence.

The temporal aspect of narrative is not entirely absent though from ancient discussions of enargeia. ${ }^{67}$ In the progymnasmata of the Imperial age, actions figure beside static objects as a potential subject of ekphrasis which is defined more or less by enargeia. ${ }^{68}$ Demetrius even discusses suspense as an aspect of enargeia in his essay On Style: "We should not state the fact at once, but unfold it gradually, thus keeping the reader

65 On this passage, see Avenarius 1956: 130-40.

66 Cf. Zanker 1981: 309-10; Manieri 1998: 106; 123 with n. 404.

67 An interesting reflection on historiography and narrative time in a different context can be found in Diodorus 20.43: historiography can imitate events, but will fall short in that it has to present simultaneous events sequentially.

68 CF. Webb 2009: 67-8.

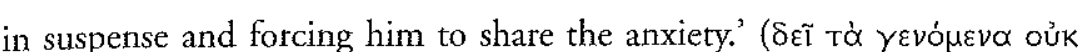

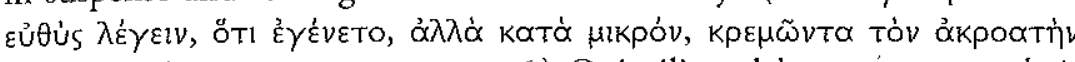

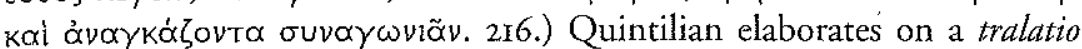
temporum or metastasis (Inst. 9.2.4I):

We can form a picture not only of things past and present, but also of things future or of what might have been future. Cicero in Pro Milone gives a marvellous account of what Clodius would have done if he had secured the praetorship.

nec solum quae facta sint aut fiant sed etiam quae futura sint aut futura fuerint imaginamur. Mire tractat hoc Cicero pro Milone, quae facturus fuerit Clodius si praeturam invasisset. ${ }^{69}$

Making the past present includes evoking its own temporal horizon; in yoking together the perspectives of agent and historians, the form of futurum fuisse condenses the concept of the future past into a grammatical tense. These reflections notwithstanding, the visual appeal is far more prominent in ancient discussions of enargeia and gives the term a nuance that is different from my concept of experiential narrative which is centred on time. Therefore, while using the terms 'experiential' and 'mimetic' more or less synonymously, I will distinguish them from the ancient concept of enargeia.

\section{Outline}

Goals

Being located at the intersection of the theory of history, narratology and Classics, 'futures past' combines theoretical reflections with close readings. More specifically, it builds on the close link between time and narrative that the narrator of Der Zauberberg notes: 'Time is the element of narrative just as time is the element of life, inextricably entangled with it as with the bodies in space. '70 Paul Ricoeur makes the link even stronger, arguing that time becomes human to the degree that it is articulated in the mode of narrative, and that a story receives its full significance when it becomes a condition of temporal existence'. ${ }^{\mathrm{T}}$ If we focus on narrative and pay it closer attention

69 See also Quintilian's exemplary account of a murder in 6.2.3 I-2.

70 Mann r926: 706: 'Die Zeit ist das Element der Erzählung, wie sie das Element des Lebens ist, Mann 1926: 706: 'Die Zeit ist das Element der Erzählung,

71 Urdösbar damit verbanden, wie mit den Körpern im Raum.' Ricoeur I983-5: 1: 85: '... que le temps devient humain dans la mesure où il est articulé sur un mode
narratif, et que le récit atteint sa signification plénière quand il devient une condition de l'existencc temporelle'. 
than Ricoeur does, we can say that time is a fundamental category of our lives and simultaneously a technical aspect of narrative. ${ }^{72}$ Both points are intricately linked: the narrative treatment of time is far from being merely a technical aspect that is exhausted by identifying 'anachronies' and labelling modifications of speed and frequency, but can be read as a mode of coming to grips with temporality. While politics and the notion of authority tackled in some of the most fruitful recent studies of ancient historiography do not play a major role in 'futures past', this focus on time pushes it beyond formalism. Time is an important aspect of the organization of narrative, but, as emphasized in my approach, has simultaneously an existential dimension.

In its exploration of time and narrative, 'futures past' hopes to make a threefold contribution to scholarship. It first takes up the interest in experience that looms large in the current theory of history. As I have outlined in the preceding section, scholars eager to break the spell of the linguistic turn have identified experience as an antidote to it. Against Ankersmit's and Gumbrecht's inclination to pit it against narrative, I try to demonstrate narrative's capacity for experience. Narrative is a medium of representation, but its doubling of experience renders it particularly apt to make the past present. My approach thus aims at mediating the insights of the linguistic turn with its critique by the 'New Romanticists'.

Second, the readings of 'futures past' draw heavily on the arsenal of narratology. The categories established by scholars such as Genette and Bal have significantly enhanced our understanding of the workings of narrative. ${ }^{73} \mathrm{~A}$ new generation of scholars though has broken new ground and has widely broadened the scope of narratology: 74 the focus on narrative has given way to intermedial studies, a new footing in cognitive science has been found and various fields such as philosophy, psychology and anthropology have developed their own narratologies. Not all of these innovations have been welcomed by traditional narratologists who fear that their discipline has been watered down and become a label that is as arbitrary as it is fashionable. 'futures past' tries to do justice to both the heritage of classical narratology and the more recent impulses. It deploys the established categories of narratological analysis, but makes them fruitful for questions beyond its scope. More precisely, it offers an exercise in using narratology as a heuristic tool to explore how narrative helps us come to grips with our temporality. ${ }^{75}$

${ }_{72}$ For such an approach, see Grethlein 2orod. ${ }_{73}$ Genette 1980 [1972]; Bal 1977.
74 For a survey of the recent development in narratology, see Nünning 2003.

75 For this take on narratology, see Grethlein and Rengakos zoro.
Third, ancient historiography has established itself as arguably one of the most prolific fields in Classics. Hayden White's Meta-History as well as Woodman's focus on rhetoric has prompted scholars to take seriously the narrative art of ancient historians and to consider it less as detracting from veracity than as generating historical meaning. ${ }^{76}$ The more recent developments in the theory of history, into which my approach taps, notably the interest in presence, promise to yield similarly rich returns for the study of ancient historiography. While the notions of closure and enargeia have already attracted some attention, ${ }^{77}$ the agenda of 'futures past' permits a new systematic look at the temporal dynamics of ancient historiography. It helps to complement the investigation into how historians create historical meaning with an analysis of how they make the past present or master the vagaries of time through retrospect. Besides enhancing our understanding of the narrative craft applied in individual texts, this approach also yields a new perspective on the history of ancient historiography. New links will emerge that enrich our view of the dialectic between innovation and tradition, for example when the notion of mimesis in Hellenistic historiography is reconsidered in light of Thucydides' striving for vividness, or when on the other hand the prominence of teleology lets us see Sallust as closer to Herodotus and Polybius than to Thucydides.

\section{Focus}

The range of works discussed in 'futures past' is simultaneously narrow and broad. The balance between teleology and experience applies to any kind of narrative and could also be explored in works of fiction. This is illustrated by the comparison of epic and dramatic poetry by Schiller and Goethe who ponder on a similar tension: in their view, the dramatic desire to make the action present goes against the distance that is characteristic of epic. ${ }^{78}$ By the same token, Ortega and Bakhtin contrast the closedness of the epic past with the openness of the novel. ${ }^{79}$ In the field of classical literature, Winkler has elaborated on the relation between auctor and actor in Apuleius' Golden Ass, demonstrating the novel's focus on its protagonist's experience. ${ }^{80}$ Homeric epic serves as an example for teleological narratives,

${ }^{6}$ Cf. especially White 1973 ; Woodman 1988. For an extremely polemical attack against these approaches, see Lendon 2009 .

77 On closure, see, e.g., Marincola 2005 (survey); Pelling 2002h (=1997) (Plutarch's Lives); Boedeker 1988 (Herodocus); Levene 1992 (Sallust); on enargeia, see, e.g., Walker 1993 (survey); Davidson 199r (Polybius). On narrative time in general, see Hornblower 1994; Rood 1998; de Jong 1999; the contributions to Grethlein and Krebs 2012.

${ }^{78}$ Cf. Jauß I955: 18-23. $\quad 79$ Ortega y Gasset 1925; Bakhtin 198I. $\quad{ }^{80}$ Winkler 1985. 
as its juxtaposition with drama and novel suggests; at the same time, Strauss Clay's recent study Homer's Trojan Theater draws attention to features that make the heroic past tangible for the audience. ${ }^{8 \mathrm{I}}$ The epic aspiration to presence is explicitly phrased by Lucan in $B C_{7.210-13}$ :

... When wars are read, they will excite hopes and fears together and useless prayers; and all men will be spell-bound as they read the tragedy, as if it were still to come and not past; and all will still take sides with you, Magnus.

... cum bella legentur spesque metusque simul perituraque vota movebunt attonitique omnes veluti venientia fata non transmissa, legent et adhuc tibi, Magne, favebunt.

That the tension of 'futures past' is central to narrative comes to the fore in Brooks' reflection on the reading process: 'Perhaps we would do best to speak of the anticipation of retrospection as our chief tool in making sense of the narrative, the master trope of its strange logic. ${ }^{82}$ It seems nonetheless reasonable to sharpen the focus of this study and limit its scope to historiography: experience and teleology, while shaping narrative in general, gain special significance through the historians' claim to report what has happened. ${ }^{83}$ It is not their aim to represent any experience and construct any teleology, but to do justice to actual experiences and historical connections. While not being identical with the objectivism of modern positivist historians, the ancient claim to veracity sets historiography off from other genres such as epic and tragedy. Through the referential claims of historiography, the balance between experience and teleology becomes more than a mere stylistic device for enticing the reader; it involves the notion of what history is - the experiences of the historical agents or the great lines drawn in retrospect.

At the same time, 'futures past' is not limited to historiography in a narrow sense. The reader will find discussions of Xenophon's Anabasis

8I For some qualifications of epic teleology, see, e.g., Grethlein 2006a: 257-83; on the presentness of the heroic past, see before Strauss Clay 2010 especially Bakker 1993.

82 Brooks 1984: 23 .

83 The factual character of historiography also affects an important narfatological issue, namely the

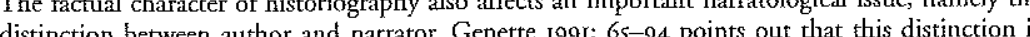
distinction between at hor and naphe not necessary in factual narrative, for which the a a has fortiori to ancient historiography: Sallor 2008: 7 observes that the distinction is unknown in ancient criticism and Pelling 2009: 149 n. 5 makes the important point that ancient historians often speak with 'the "atthority" of reas-life political experience'. I nonetheless side with Gribble 1998: 46 and will in most cases prefer to speak of the narrator in order to highlight that I am referring to the rhetorically fashioned narratorial persona instead of the biographical subject. The Anabasis, which was obviously not published under the name of Xenophon, is a case that helps justify this reticence even in ancient historiography. and Plutarch's Lives as well as of the works of Thucydides and Tacitus. In reconsidering Jacoby's approach to Greek historiography, Marincola has made the important point that many of the fine generic distinctions such as Zeitgeschichte, chronography and mythography lack evidence in our ancient sources. ${ }^{84}$ Even the distinction between historiography and biography that Marincola takes for granted seems to be less than clear-cut. ${ }^{85}$ The aspects investigated in 'futures past' are not restricted to the political monograph that is still sometimes deemed real historiography, but equally apply to other forms of narrating the past. In order to fully explore the dynamics of 'futures past' in ancient historiography, it thus seems wise to consider a wide range of historiographic texts. Two chapters will even go beyond this frame to throw into relief the findings, the first in discussing a nonhistoriographic text, Augustine's Confessions, the second in tackling modern historiography.

\section{Synopsis}

The primary principle for arranging the chapters of Experience and Teleology in Ancient Historiography is not chronology. There is no development from Herodotus to, say, Tacitus; the treatment of experience and teleology in ancient historiography does not lend itself to a teleological account. Nor does genre seem to be a decisive factor: Herodotus' Histories and Tacitus' Annals, for example, both deal with events completed in an earlier generation, but whereas the former has a strongly teleological design, the latter is more experiential. While Thucydides account of the Peloponnesian War tries hard to restore presentness, Sallust's Bellum Catilinae, another monograph of a recent event, foregrounds teleology. Neither genre nor date determines a history's take on the 'futures past'. In certain historical circumstances either experience or teleology may have a special appeal, and either may be more or less conducive to the scope of a historiographic genre, but ultimately each historian is free to prefer one over the other.

Instead of time and genre, I have chosen the two poles of 'futures past' as organizing principle and have grouped together works that lean towards experience and works that gravitate towards retrospect. While this structure

84 Marincola r9g9a. See also Pelling 1999 for a more fexible notion of genre in historiography that starts from the expectations of readers.

8s Marts from the expectations of readers. between historiography and biography, but has been successfully challenged, e.g., by Gencili and Cerri I988. For a survey of the debate, see Schepens 2007. 
is best suited to the agenda of 'futures past', it comes at the price of some ambiguity. As I have pointed out, it is hard to find accounts that manage to reject fully either aspect. The attribution of authors to the two parts is therefore not absolute, but one of tendency, and I will also consider teleological aspects of the works discussed in the part on experience and vice versa. The chronological arrangement of authors within the parts on experience and teleology owes more to the train of argument than to an attempt to construe a development.

Let me mention one further limitation: 'futures past' does not aim at an exhaustive treatment of the vast corpus of ancient historiography, but is limited to case studies. I have tried to select texts that help elucidate different aspects of experience and teleology while also covering a variety of genres and periods. That being said, many other authors would yield fascinating material; just to touch upon two: the prominence of spectacle in Livy's Ab urbe condita highlights its experiential potential, while the role of space as examined by Jaeger helps to cement a teleological design. ${ }^{86}$ Flavius Josephus' Antiquitates is another universal history that, besides inviting comparison with $A b$ urbe condita, would allow consideration of the impact of the Jewish tradition on the 'futures past'. If the reader misses discussion of these and other texts, I hope that, instead of seeing this as a deficiency of Experience and Teleology in Ancient Historiography, she takes it as a sign of the fruitfulness of its agenda.

The individual chapters try to do justice to the intricacies of an author's take on experience and teleology and interact with each other in manifold ways. Nonetheless, the trajectory of the main argument can be summed up in the following way: the mimetic quality of 'Thucydides' narrative has already been noted in Antiquity. Instead of discussing one of the muchhailed passages such as the battle in the harbour of Syracuse, I engage in a close reading of Phormion's two naval victories and the capture of Mytilene in order to demonstrate how relatively minor incidents are rendered experiential by Thucydides (II). Xenophon is often considered an epigone of Thucydides, but the Anabasis illustrates a mastery of experiential narrative that has nothing to fear from comparison. While Chapter 2, on Thucydides, offers a sequential reading of two select episodes, this chapter provides a thematic exploration of important devices for making the past present: focalization, graphic description, speeches, 'sideshadowing', closure (III). Plutarch extols Thucydides and Xenophon for their enargeia, but the Alexander illustrates that the mimesis achieved in the Lives is different

${ }^{86}$ Cf. Jaeger 1997. On spectacle in Livy, see Feldherr 1998. from the experiential quality of their works. The episodic structure of the Alexander downplays temporal sequence; at the same time, Plutarch elaborates scenes that are strongly appealing visually and help to drive home his moral points (IV). The account of Germanicus' visit to the Teutoburger Wald, I suggest, can be read as an implicit reflection on the mimetic quality of Tacitus' Annals. While the preceding chapters demonstrate that an author's admission of uncertainty interrupts the narrative mimesis, the death of Germanicus and the Pisonian Conspiracy, on the other hand, illustrate that ambiguity can enhance the experiential appeal of an account (V).

The first part focusing on experience is complemented by a second part assembling chapters which concentrate on teleology. In Herodotus' Histories, the commemorative practice of Darius and Xerxes highlights the fact that history can only be told in retrospect. Accordingly, the Histories are strongly teleological, while also demonstrating that even once events have come to an end historical meaning is not stable and shifts with the vantage point of the beholder (VI). The idea of a symploke gives Polybius' universal history a strongly teleological design, which will be thrown into relief through a comparison with Aristotle's concept of plot and the modern notion of history. At the same time, Polybius is aware of the intricacies of teleology and offers some penetrating reflections on them. Moreover, despite his polemic against Timaeus and others, he showcases from time to time gripping mimetic accounts (VII). Sallust's presentation of the Catilinarian Conspiracy against the backdrop of Rome's decline after the destruction of Carthage reveals a further aspect of teleology: not only are events shaped by the choice of a later point of view, but also the events chosen as telos are highly charged. As teleological as the $B C$ is, it encapsulates two alternative assessments of the conspiracy that rival its main plot-line (VIII).

In the third part, I will look beyond historiography in order to throw the findings of the two main parts into relief and to deepen the inquiry into the dynamics of 'futures past'. Through the convergence of experiencing and narrating instance in one person, autobiography exacerbates the tension between experience and teleology. In addition to this, Augustine's Christian agenda renders the take on the 'futures past' in the Confessions special. While featuring experiential passages, notably the conversion scene in book 8 , the narrative design of the Confessions is deeply teleological. At the same time, I will argue that Augustine strives to come close to God's take on history which, in transcending both experience and teleology, is a-temporal (IX). In the Epilogue, I will return to the current debate on history and 
experience and review some attempts of contemporary historians to restore presentness to the past in light of the strategies found in the works of ancient historians. Together with teleology, experience has remained a pole of narrating the past, but modern scholars trying to make the past present face new challenges $(\mathrm{X})$.

PART I

Experience: making the past present 